\title{
THERMOGRAPHIC TESTING OF EPOXY-GLASS COMPOSITE TENSILE PROPERTIES
}

\author{
M. Kutin", S. Ristić, M. Puharić, M. Vilotijević, M. Krmar \\ Institute Goša, Belgrade, Milana Rakića 35, Serbia
}

\begin{abstract}
The results obtained in the parallel testing of the epoxy-glass composite specimen, using conventional mechanical methods and thermography, are presented. The tensile properties of composite were followed by thermography. The temperature changes on the tested sample were continuously recorded enabling the prediction of the critical stresses, which might cause the fractures and to define the criteria on the maximum sample temperature alteration in the field of the elastic and elastic-plastic deformation of investigated specimen.
\end{abstract}

Keywords: tension, thermography, fracture mechanics, glass-epoxy composite.

\section{INTRODUCTION}

Classical methods of composite materials testing are well known [1-10]. Very important characteristics, can be obtained by tensile tests; yield strength, tensile strength, elongation, etc. These characteristics describe the global mechanical behavior of composite materials $[5,8]$. Regarding to the exploitation safety of structures of composite made parts, the most important are the characteristics, describing the appearance and growth of the fatigue cracks under the impact of the static and dynamic loads. Monitoring and diagnosis of complex structures in operation, requires the application of nondestructive, contactless method.

The basic characteristic of the nondestructive methods is testing without compromising the integrity of objects, their technological and functional performances [1]. Any object above absolute temperature emits electromagnetic radiation in the infrared region of the electromagnetic spectrum. The $\mathrm{r}$ adiated energy is a function of surface temperature. Infrared Thermography Technique (IRT) has been used as a non-destructive noncontact and real time method for capturing the thermal energy being radiated from the surface $[2,5,7,10]$. Thermography provides analysis of thermoelastic stress, based on the measurement of infrared radiation, emitted by the component surface, exposed to dynamic or static, 1inear elastic or plastic strain and its conversion into visible image, thermogram. The thermogram can $r$ eveal the difference between the parts of object surface that emit different amounts of infrared radiation.

"Corresponding author: marina.kutin@institutgosa.rs
These areas are represented by shades, gray or colors that are assigned to different levels of emissivity.

At present, thermography is used in almost all area of human life: technology, energy, medicine, biology, criminology, etc. In order to calculate the temperature of the monitored object from the radiation reaching the camera sensor and link it with stresses and early fatigue, it is necessary to know emissivity of the object surface, temperature of the surrounding objects, camera distance from the tested object, thermal losses, air temperature and relative humidity. Based on this necessary conditions, it is very difficult to apply infrared thermography for large objects inspection under the exploitation conditions. The parts of the calibration tests should be performed in laboratory conditions.

The beginning of industrial application of IR thermography is related to 1965 , when the first equipment with cooled detectors has been manufactured, whereas the first model with micro bolometer has been introduced in 1997 Image quality improving enabled the entry of correction factors for the necessary compensation, directly into the camera $[1,2]$. Thermography has become one of the most important methods in preventive maintenance systems in many industrial appliances [1-10].

Thermography was rapidly evaluated from laboratory method into a practical one, very comfortable for the test, and is used in different varieties. Thermography can be a "passive" and "active". The first detect body radiation at higher or lower temperature than ambient,. The active thermography detects the radiation of the body, as a result of heat transferred into the tested object. Convection is a ba- 
sic mechanism of the heat transfer in the solid bodies. If the body has a defect or inhomogeneity, the uneven heat expansion will appear, resulting in uneven radiation of particular parts as well.

\section{EXPERIMENTS}

Experimental setup for composite specimen's tensile test is illustrated in the fig. 1. During the experiment, a number of samples ware examined. Tensile testing and thermographic measurements were performed simultaneously [10].

\subsection{Composite specimen's tensile test}

When a material is subjected to tensile loading, from zero to its elastic and then to plastic regime under adiabatic conditions, heat transfer occurs. Both elastic and plastic deformation changes the temperature of the material. During tensile elastic deformation, the material is cooled due to volume expansion and the plastic deformation, causing the rise in temperature of the specimen. Due to the coupling effect of thermal and mechanical behavior, measurement of temperature response can provide better understanding of the deformation.

The tests of composite specimens were carried out on the electromechanical testing machine PM 100 , with displacement and the strain (extension) control at room temperature. The tension speed was $1 \mathrm{~mm} / \mathrm{min}$. The extension was registered using double extensometer. The accuracy of extensometer measurement is $\pm 0,001 \mathrm{~mm}$.

A series of glass-epoxy composites was tested. Composite materials, due to its deformability, light weight, high strength and modulus, low density, good impact and dynamic strength, resistance to crack growth, good resistance to oxidation and corrosion, are increasingly being applied in complex structures under the extreme conditions. Combining high strength and stiffness of the strengthening fibers with matrix plasticity, materials of high technical performances are obtained.

Figure 2a shows the specimen at the end of experimental test. Specimen is made of $68 \%$ of longitudinal glass fibers in immersed in epoxy, while Figures $2 b$ shown photos of specimen recorded by optical microscope with magnification of 50x.

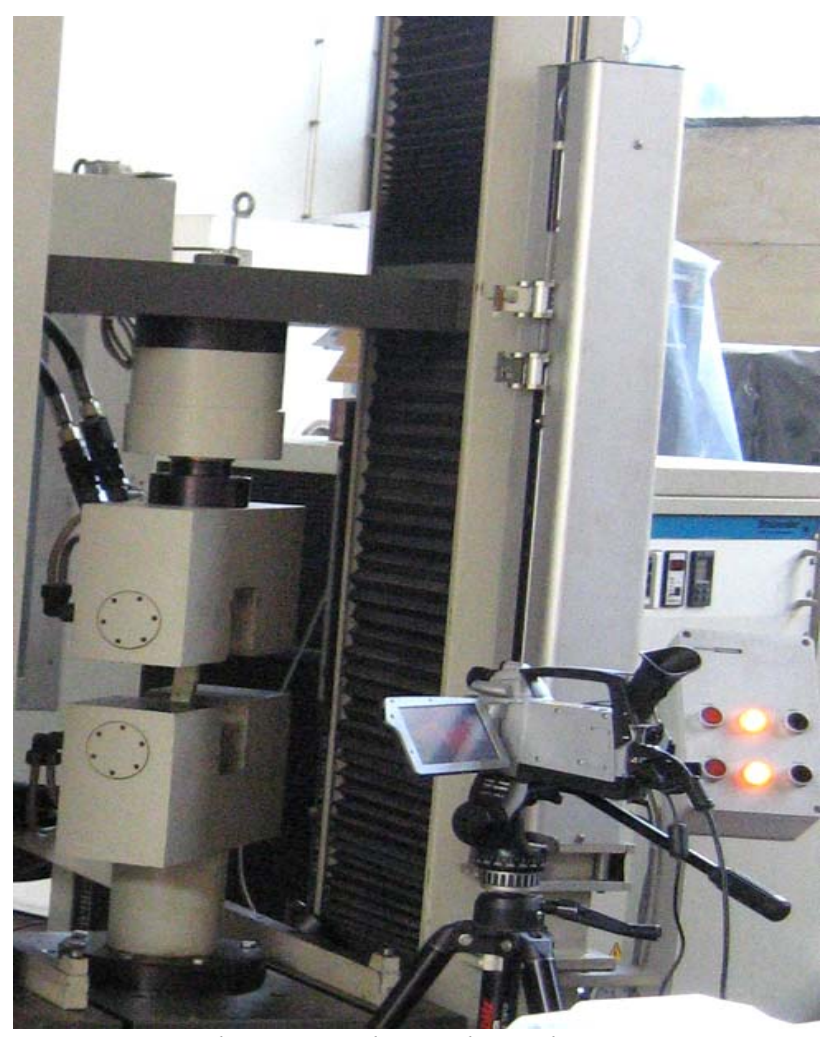

Figure 1. Thermographic and tensile test equipment

\subsection{Thermographic setup}

Therma CAM SC640 Infrared camera, FLIR Systems, has been used for recording thermogram. The camera resolution is $640 \times 480$ pixels. It was positioned on the distance of $0.5 \mathrm{~m}$ related to the sample surface. Camera sensitivity is $60 \mathrm{mK}$ at $30^{\circ} \mathrm{C}$, field of vision is $24^{\circ} \times 18^{\circ}$, minimum focus distance is $0.3 \mathrm{~m}$, spatial resolution is $0.65 \mathrm{mrad}$, recording frequency is $30 \mathrm{~Hz}$ and electronic zoom is $1-8 \mathrm{x}$ continuously. Detector type is Focal Plane Array, noncooled microbolometer $640 \times 480$ pixels [2].

Camera spectral range is 7.5 to $13 \mu \mathrm{m}$, whereas the temperature range is from $-40^{\circ} \mathrm{C}$ to $+1,500^{\circ} \mathrm{C}$, divided in three intervals; i.e. it can optionally operate up to $+2000^{\circ} \mathrm{C}$, with precision of $\pm 2^{\circ} \mathrm{C}, \pm 2 \%$. There is a possibility of measuring temperature in the spot, on the line at the given surface of the various shape and dimensions, to show isotherms using gradient of grey or the palette of various colors and shades. The camera is provided with the automatic correction of emissivity and atmospheric transmission based on the distance, atmospheric temperature and relative humidity.Video and thermographic recording or track is simultaneously $[2,10]$. 


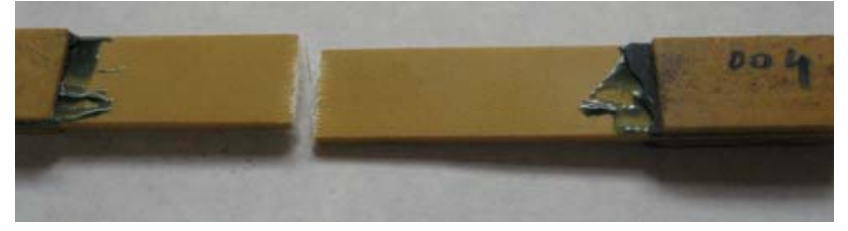

a

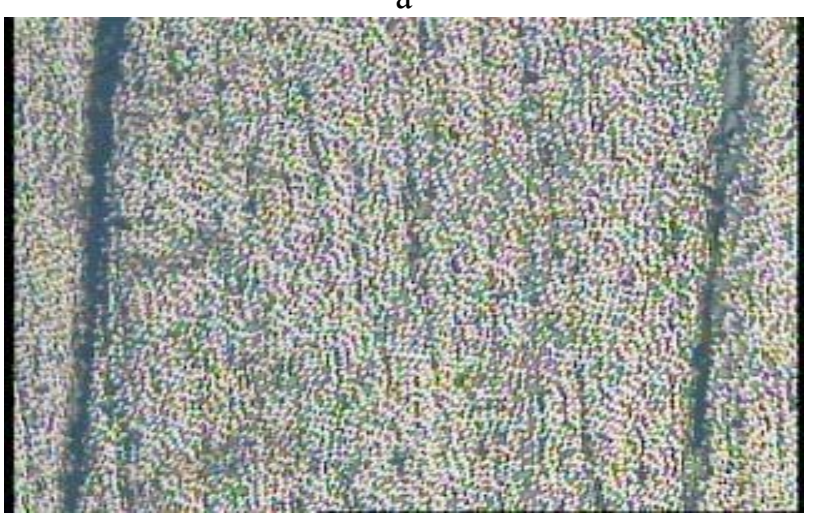

b

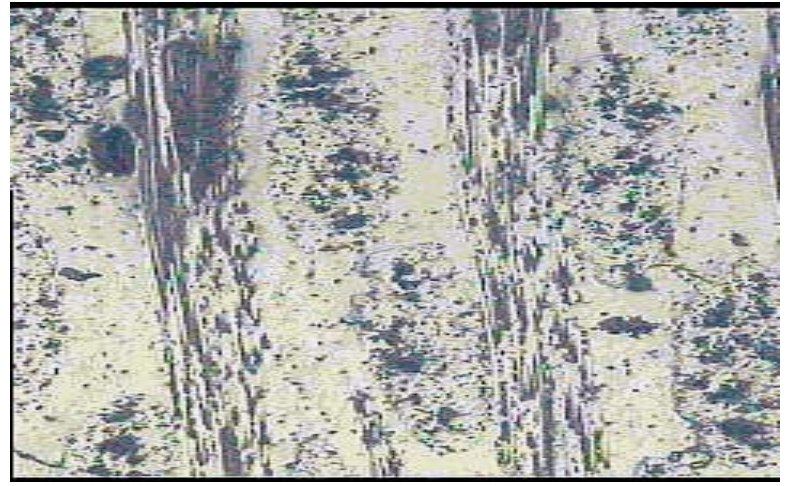

$c$

Figure 2. Epoxy-glass composite spaciment, a) spacement after test, b) and c) photos of tested spacement by optical microscope

\section{RESULTS AND DISCUSSION}

Damages in composite materials are the subject of many studies. Many methods, both destructive and non-destructive, are developed for evaluation of the origin and development of damages, which can be very complex. The damage can be manifested as different combinations of cracks in the matrix, breaking the link between fiber and matrix, delamination and local fiber defects. Composite damages depend on many factors, primarily on the structure of materials, number of layers, the orientation of fibers, the modeling process, the stress and loads they are exposed to.

One of the main areas of research is testing tensile properties of composite materials. It is possible to determine: modulus of elasticity, tensile strength, strain and Poisson's ratio. These parameters are indicators of material behavior under tension.
The Understanding of micro mechanism of defect in composite materials, which occur during the load, is very important, because information on these mechanisms contribute to comprehensive composite materials.

The defects of composite materials can be in the form of cracks in the matrix, broken links fibermatrix, fiber break and delamination. The increasing of stress concentration in the layer causes cracks or the growth of existing ones. The crack is spread through shear stresses through the matrix to adjacent layers.

Breaking of the connections between fiber and matrix is a phenomenon that is characterizes poorly impregnated fibers. Toughness of the composite material is directly dependent on the adhesion. Fiber fracture occurs when the fiber has micro defects. In this case the adjacent fibers the larger load leads to their cracks.

Tested specimens ware made of unidirectional glass-epoxy composite, consisting of $68 \%$ glass fibers immersed in epoxy matrix. During stretching the composite spacemen, thermography showed an increase in tempereture.

Changes in temperature, under real non adiabatic conditions are the result of several mechanisms. It is difficult to define the boundary between thermo elastic and thermoplastic effects and to separate their contribution to the total temperature changes. In practice, non adiabatic systems, such as the investigated one, come up to heat exchange with the environment, which directly affects the temperature of the tested specimen.

Parallel application of thermography and tensile test of composite specimen's show that the temperature changes during the test are relatively small. Figure 3 is a diagram of stress - elongation of investigated glass-epoxy spacemen. The specimen crack has occurred at the end of fourth seconds. Total elongation of the glass-epoxy is about $60 \mu \mathrm{m}$.

During tests, thermographic camera detected the temperature changes on spacemen surface and made the continuous data colection. The figures $4 a-$ $4 \mathrm{~g}$ shows the selected sequences. These figures are the thermograms that show the locations where there has been an increase in temperature and eventually crack the spacemen.

The temperature distribution on the surface of the sample during the tension was obtained by software Thermo CAM Researcher, based on MS Windows operating system. Figures $5 \mathrm{a}, 5 \mathrm{~b}$ and $5 \mathrm{c}$ thermograms, show the distribution of temperature along the measurement lines on the surface of the specimen and tabular values for the maximum temperatu- 
re at the moment. The temperature of epoxy glass spacemen at the time of crack was about $37^{\circ} \mathrm{C}$.

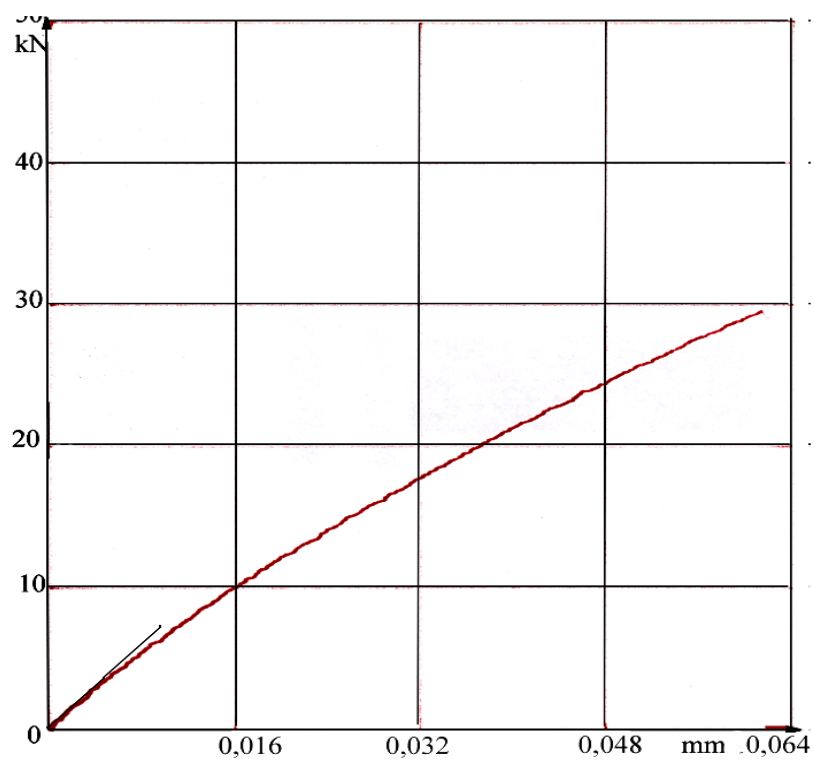

Figure 3. Force-elongation diagram for epoxy-glass composite

The test on glass-epoxy specimens has shown that it has greater toughness than the graphite-epoxy

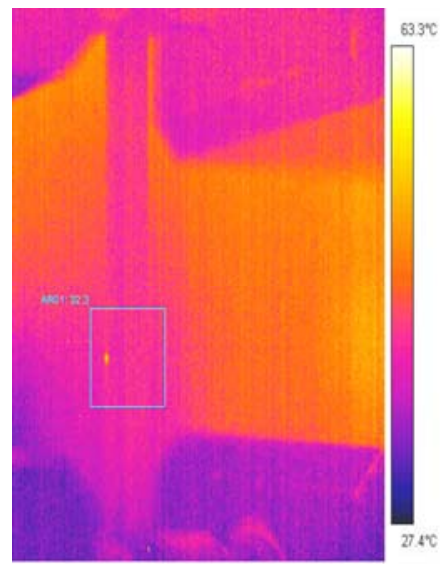

$a$

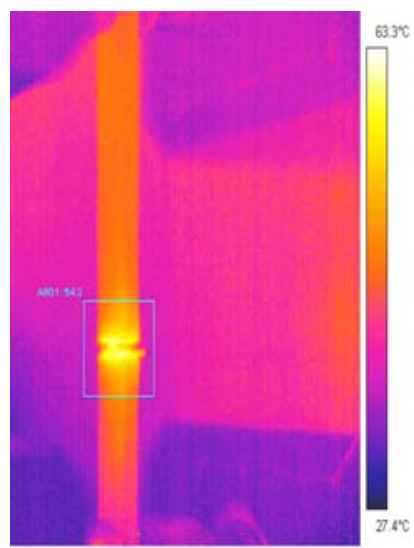

$c$ specimens, as expected. The crack of the specimen began $3.5 \mathrm{~s}$ after start and ended after an additional $0.4 \mathrm{sec}$ of stretching and at the force of nearly $30 \mathrm{kN}$. This specimen is warmed from the initial $28.5^{\circ} \mathrm{C}$ to $65.5^{\circ} \mathrm{C}$, as shown in Figure 4. Elastic sample elongation was in the first $0.3 \mathrm{~s}$, and then a plastic deformation started. Thermo camera registered a slight drop of temperature range, $\Delta \mathrm{T}=0.3^{\circ} \mathrm{C}$, during first $0.2 \mathrm{~s}$. The temperature starts to rise after that. (Figs. $5)$.

Values of temperature were obtained with software tools named lines. The temperature is monitored simultaneously in three line items, placed in the characteristic zones, where a specimen was cracked. Thermographic equipment makes it possible to read the temperature changes every $33 \mu$ in $640 \mathrm{x}$ 480 pixels, during recording or on the basis of taken thermographic records.

The resolution of the camera, used in the experiment was $60 \mu \mathrm{K}$. It is clear that the measured values of temperature changes are the base for the prediction of areas with a concentration of stress and possible cracking.

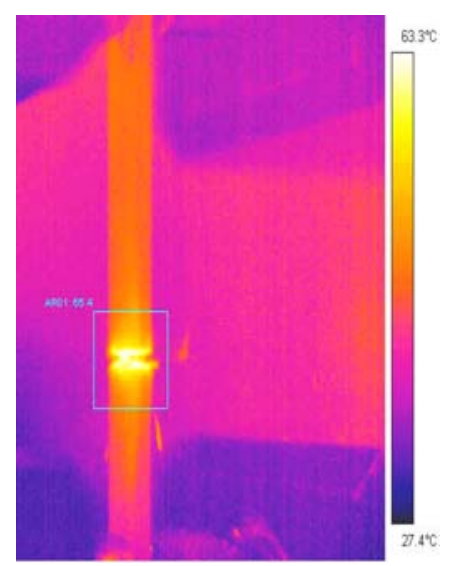

$b$

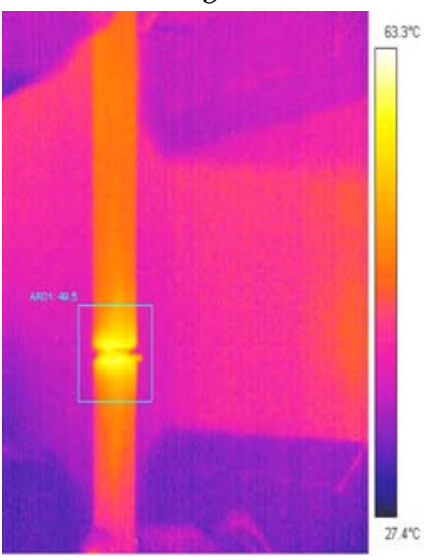

$d$

Figure 4. Thermograms obtain in laboratory tests prior to testing real plants in real conditions. 

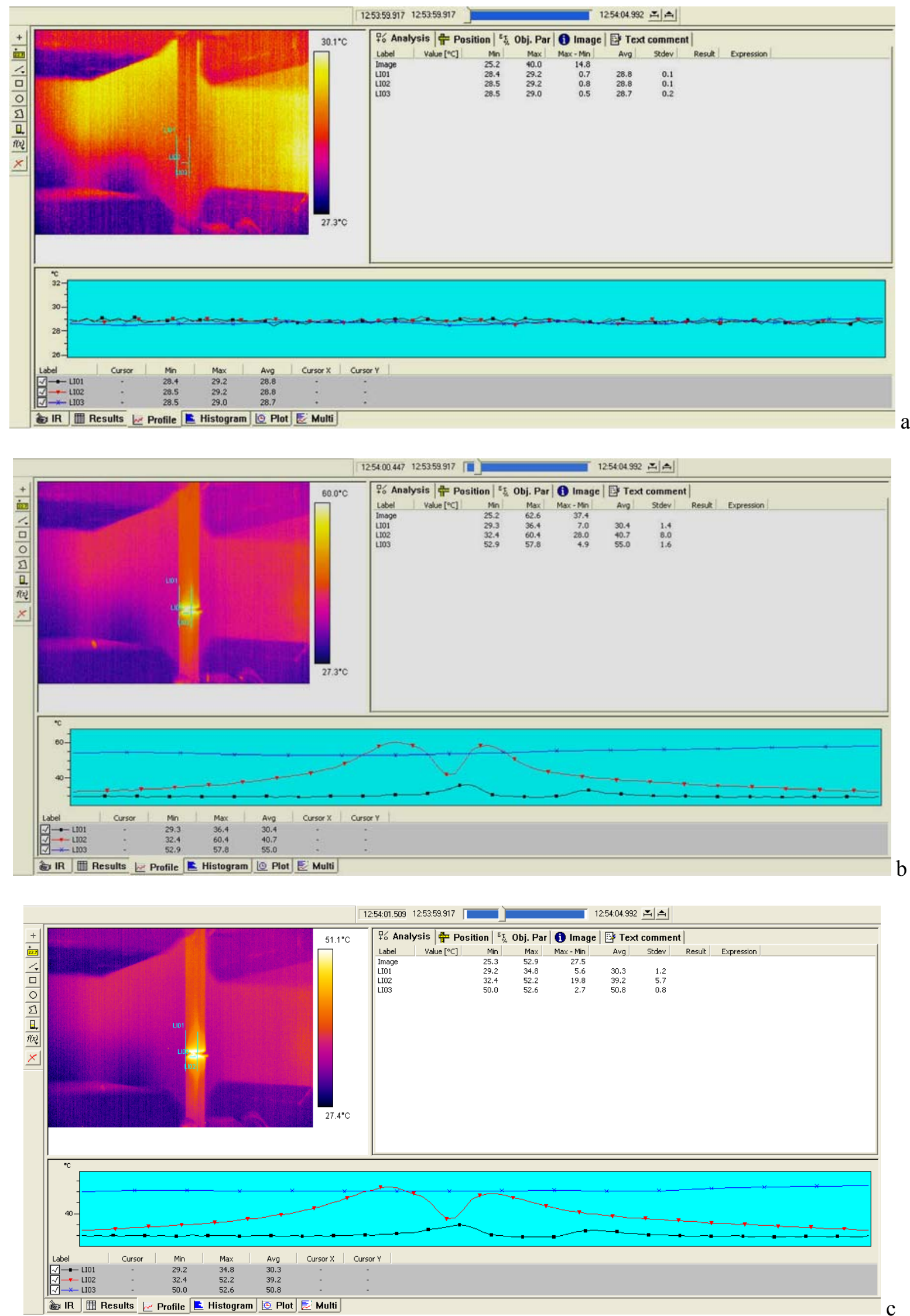

Figure 5. Temperature distribution along the measurement lines on the surface of the specimen during extension 


\section{CONCLUSION}

Infrared Thermography technique was employed for characterizing tensile deformation of glass/epoxy composite specimens. Test results obtained by classical methods and thermography are presented simultaneously. On the base of comparative analysis, the criteria for the application of thermography in non-contact testing and prediction of occurrence of damage in complex structures made of composite glass-epoxy material could be defined.

Based on temperature changes, Thermography can indicate the zones of stress and strain on the entire surface of the tested object, not affecting the integrity of the sample, in part or as a full construction. Obtained results confirm that it is very useful to use thermography for early diagnostics of complex structures under the real conditions.

\section{ACKNOWLEDGEMENTS}

This work was financially supported by Ministry of Science and Technology of the Republic of Serbia under the project TR 19205.

\section{REFERENCES}

[1] X. P. Maldague, Nondestructive evaluation of materials by infrared thermography, Springer-Verlag, London, 1993.

[2] Flir Systems, The Ultimate Infrared Handbook for R\&D Professionals, verzija 1.

[3] M. Toughiry, Examination Of The Nondestructive Evaluation Of Composite Gas Cylinders, final report, A7621-18:CRC-CD8.1, September 2002

[4] T. J. Fowler, V. K. Kinra, K. Maslov, T. J. Moon, Inspecting FRP Composite Structures with Nondestructive Testing, Report Number 1892-1, Center for Transportation Research Bureau of Engineering Research The University of Texas at Austin, 2001.

[5] J. S. M. Johnson, Infrared thermography and thermoelastic stress analysis of composite materials and structural systems, A Thesis Georgia Institute of Technology, August 2006

[6] M. Kutin, S. Ristić, M. Puharić, Thermographic recording of laser light and composite material interaction, 31.HIPNEF 2008, 15. - 17. 10. 2008, Vrnjačka Banja.

[7] N. P. Avdelidis, B. C. Hawtin, D. P. Almond, Transient thermography in the assessment of defects of aircraft composites. Journal of NDT \& E International, 36 (2003) 433-439.

[8] R. M. Haj-Ali, and R. F. El-Hajjar, Crack propagation analysis of Mode-I fracture in pultruded composites using micromechanical constitutive models, Mechanics of Materials, 35-9 (2007) 885902.

[9] M. Toughiry, Examination Of The Nondestructive Evaluation Of Composite Gas Cylinders, The Nondestructive Testing Information Analysis Center, A7621-18: CRC-CD8.1, 2002.

[10] M. Kutin, S. Ristić, Z. Burzić, M. Puharić, Testing of butt welded thin steel sheet by classical method and thermography, Proceedings of 3th OTEH 2009, 8-9 oct.2009, VTI, Belgrade, Serbia, 2009, IHMTZ/10.

\title{
ТЕРМОГРАФСКО ИСПИТИВАњЕ ЗАТЕЗНИХ ОСОБИНА КОМПОЗИТА ЕПОКСИ СТАКЛА
}

\begin{abstract}
Сажетак: Резултати су добијени упоредним испитивањем стакло-епокси композитних узорака методама испитивања механичких карактеристика материјала и термографијом. Промене температуре на тестном узорку снимљене су у континуитету омогућавајући предвиђање критичних напона који могу да узрокују преломе и да дефинише критеријуме за максималне промене температуре узорака у области еластичног и еластично-пластичних деформација испитиваних узорака.

Кључне ријечи: напетост, термографија, механика лома, стакло-епокси композити.
\end{abstract}

